\title{
Adaptation of children with illnesses of the motor organs to hospital conditions
}

\begin{abstract}
Introduction. It seems that the society should accept the legal and moral responsibility and the care over the injured individuals due to their health problems. Medical staff, doctors and nurses play a major role in the care of children, it is them who are in a direct contact with them in the course of the stay in hospital. The reaction of a child, as an exceptional patient, is quite varied as for the stay in different institutions. Patience, warmth and understanding are features which are necessary in the adaptation to conditions of the treatment. The medical professionals somehow replace parents and care providers, and create home-like environment for these children which means they can always count on help and understanding.

Aim. The purpose of this research was to portray children in hospital as well as their stance toward the current situation, expectations, pleasures and aversions.

Material and methods. The authors of the study examined 20 patients of a surgical clinic, both girls and boys. They applied the method of the diagnostic survey. The research was done using theinterview technique based on contents of unfinished sentences. 12 girls and 8 boys took part in the examination.

Results and conclusion. The examinations reveal that in order to combat negative feelings and overcome loneliness amongill children, hospitals should prolong the visiting time for family and friends and locate patients in rooms according to age, sex or disease. Delivering the greater scope of information provides a sense of security to children and hence has a positive effect to the adaptation to hospital settings.
\end{abstract}

Keywords: reintegration, hospitalized child, illnesses of the motor organs.

DOI: $10.1515 /$ pjph-2015-0058

\section{INTRODUCTION}

It is medical staff that play the most important role in the care or rehabilitation processes in ill children. Doctors and nurses usually keep company from the first days of their stay in hospitals. Individual experiences might be very different. Some sick individuals quickly adapt to new conditions themselves while others do it very slowly. A lot depends on the medical staff, their patience, warmth and understanding. It is the staff that replace parents and create home for these children where they can always count on help and understanding. The behavioral observation of children encouraged authors to have a closer look at the problem since currently there is a huge amount of transport accidents and resulting from that - injuries of motor organs. In light of this, it is impossible to remain indifferent to the needs of ill children who need support and understanding [1].

This issue was accurately summarized by John Paul II who said "We do know it from our experience that in case of a disease, human warmth is needed (....). Things like work rhythm, stress, family crises, all cause a brotherly staying by one's bed to be more and more difficult. The weakest individuals always pay the price for that. It may also happen to the olderones unable to make decisions because of age, along with innocent children, other sick individuals or terminallyillpatients (....) may seem to be an obstacle which it is necessary to dismiss. Being with sick individuals, staying close to them helps us build the society, which is characterized by the respect for other people" [2].

\section{Psychological needs of ill children}

Illness and the stay in hospital create situations making it impossible to fullysatisfy one'spsychological needs. Some of these needs are intensifying or are being made aware of exactly during the illness.

Dominating in illness is a strongly felt need of help and care. It manifests itself in different degrees: from justified expectations throughcompulsive requests, or exaggerated complaints and grievances. There is also an intensifying need for safety. The most common causes of frustration included fear for one's life, patients' uncertainty of their fate, fear of painful treatments, anxious waiting for the results of the diagnosis. Here, it is the family that plays a huge role. It is the family thatprovides the greatest support during the illness. Health care workers are generally expected to express approval and sympathy. For many people, the moment an illness appears means the first time when theybecome aware of the meaning of life. The frustration related to the prospect of losing life or health 
can turn out to be the root cause of an illness or sparking some immature reactionsslowing down the healing process.

Usually, children do not want to go to a hospital. However, many a time the form of disease, injury or an accident require hospitalization. During hospital stays, both children and their parents are extremely exposed to stress. Hence, the child's developmental needs or their need to see their family should be respected. Children should be assisted in adapting to the hospital conditions so that, in the future, a hospital does not conjure up any unpleasant memories [3].

\section{Illness' impact on the psyche}

Any illness or incapacity of the human body causes a number of unpleasant psychological experiences. Illness also affects one's mental state indirectly through a round of sensory (e.g. pain, weakness, fever, restrictions of the energetic attitude to life, abandonment of current habits). Experiencing illness often causes fear and uncertainty of the fate. One is then forced to abandon their future plans, intentions or expectations. Also, new, previously unknown sensationsstart to appear - like the ones related tohelplessness, having to rely on others, as well as lossof independence and significance [4].

Finding oneself all of a sudden at a hospital can give an additional mental strain. Psychological experiences connected with illness and the hospitalization should not be regardedas an essential threat. The intensity and size of these experiences dependon a number of factors. According to M. Kulczycki these factors include: one's situation in life, their knowledge about illness, but first and foremost, personality traits or attitudes towards oneself and towards others [5]. The influence of specific illness on a child's behavioris notclearly determined by direct suffering. Regarding children with motor organ dysfunctions, this essential issue is connected with the fact that their move is either distorted, hampered or entirely ruled out.

In such situations, a fundamental background of their life and conditioning of the psychological and physical development is immobilizing. The need forfree movement is included in the essential needs of every developing human body [6]. Being aware of the appropriate courseof adaptation is important, as well as not-allowing for the isolation and falling into depressive states. Proper behavior of the staff prevents the iatrogeny and facilitates effective therapeutic work. This atmosphere exerts some positive influence oversick individuals and calms everybody, it also mitigates the side-effect manifestations of hospitalization [7].

Amongstimmobilized ill children, as a result of changes in motor organs, we distinguish two groups:

- children immobilized periodically due to the "inability" for the movement of one of the limbs;

- childrenimmobilized permanently in consequence of the illness which deprived them of the possibilities of free movement in the result of paralysis [8].

Need for movement is necessary and an impossibility of satisfying it is a main problem of the ill child. The need to lie and to immobilize is often contrary to child's nature. The isolation from the outside world, cutting off from direct communication with the usual social circle, create unusually difficult and peculiar conditions of contact with reality [8].

\section{The notion of adaptation}

According to Barbara Arusztowicz, adaptation is the accommodation, as harmonious co-existing conditioned by physical, intellectual and normal, willful and cultural development of individuals, adequately for tasks facingit in determined environmental conditions [9]. An individual must demonstrate optimal physical fitness, power, resistance to the effort, endurance. One must have the ability to properly assess a given situation, in order to draw pragmatic conclusions from it. This means, intellectual development should reach an optimal phase which also translates into sufficient knowledge and experience. Considering the adaptive abilities of man, one should direct attention to it, that one should represent the appropriate level of emotional development which will let him given to accept situations [10].

\section{Mechanisms of adaptation}

Keeping the homeostasis, i.e. balance between the organism and the environment surrounding it is one of the fundamental activities of the human body. The ability to maintain this balance is a proof of the body's adaptive abilities. In case the balance is disrupted, there appears the state called illness [11]. Every human body is supposed to acquire specific adaptive mechanisms, with which it remains durable to changing conditions. However, the borderline of acting of these mechanismsis different. In case of the prevalence of disease or disability, that is stresses, conditions are changing, the individual isn't able to satisfy the psychological, social, economic needs and the like; then the state called frustration appears [12].

Frustration is an unpleasant emotional state experienced by an individual whose aspiration to satisfying their needs is blocked.

The threshold of frustration is not equal for everyone at some individuals it is higher, at other it is lower depending on:

- the state of the nervous system of the individual;

- the subjective value of good of which the given man was deprived of;

- the training of the frustrated situation which triggers the resistance at experiencing frustration [13].

The individual reacts to frustrating situations with defense mechanisms. These could be negative and positive situations. Negative mechanisms have a form:

- of aggression

- of escape

- of projection

- of resignation

- of regression

- of repression [14].

\section{Characteristics of the Test of Unfinished Sentences}

The method of a diagnostic survey was applied here. The study was conducted using an interview technique looking at contents of unfinished sentences. For the purposes of the structure of the tool of examinations, the hints put forward by Rębowski J. (1986) and Pilch T. (1995) were used [15].

These four main categories were singled out from the questionnaire of the interview:

1. Children opinion about the reason for their stay in the hospital

2. Expectations of ill children

3. Pleasures at a hospital

4. Aversions of ill children 


\section{AIM}

To present the hospitalized child, its relation to the current situation, expectations, pleasure and aversion.

\section{MATERIAL AND METHODS}

\section{The organization and the scope of research}

The research on the adaptation of children with motor organ illnesses to hospital conditions was conducted between September and October 2013. The scope of research included: Surgical Clinic at Children's Clinical Hospital in Lublin.

\section{Characteristics of the examined individuals}

The study authors looked at the patients of Surgical Clinic. They wereboys and girls, in the age from 10 up to 16 years, all of them suffering from different diseases of the motor organs. These included: fractures, dislocations and bone traumas and those problems of soft tissues of upper and lower limbs, of inflammation of the bone etc. Two research groups were distinguished, basing on the defect type:

1. Group A - were children with illnesses of upper limbs;

2. Group B - were children with illnesses of lower limbs.

The composition of group A: 8 girls and 2 boys and 6 boys and 4 girls in group B.

The patients willingly participated in examinations. The characterization of examined individuals according to the sex is shown as follows:

TABLE 1. The sex of the studied individuals.

\begin{tabular}{|c|c|c|}
\hline Sex & $\mathrm{N}$ & $\%$ \\
\hline Girls & 12 & 60 \\
\hline Boys & 8 & 40 \\
\hline Total & 20 & 100 \\
\hline
\end{tabular}

Children's opinion about hospital stay

TABLE 2. Reaction to an opinion ,In hospital, it is ..."

\begin{tabular}{lcccccc}
\hline \hline \multirow{2}{*}{$\begin{array}{c}\text { In hospital, } \\
\text { it is ... }\end{array}$} & \multicolumn{2}{c}{ Group A } & \multicolumn{2}{c}{ Group B } & \multicolumn{2}{c}{ Total } \\
\cline { 2 - 7 } Cool & $\mathrm{N}$ & $\%$ & $\mathrm{~N}$ & $\%$ & $\mathrm{~N}$ & $\%$ \\
\hline Sad & 3 & 30 & 5 & 50 & 8 & 40 \\
\hline Different & 2 & 20 & 0 & 0 & 2 & 10 \\
\hline Boring & 1 & 10 & 3 & 30 & 4 & 20 \\
\hline Not nice/bad & 2 & 20 & 1 & 10 & 3 & 15 \\
\hline
\end{tabular}

Results presented in Table 2, tell us that children staying at the hospital had different feelings. Around 20\% of examined children from group A claimed that there is a sad atmosphere in the hospital, whichis not confirmed by children from group B. Totally, $40 \%$ of the examined claimed that the hospital is a cool place, and $15 \%$ of the whole had negative feelings.

TABLE 3. Reaction to the opinion:,Doctors and nurses are ..."

\begin{tabular}{lcccccc}
\hline \hline \multirow{2}{*}{ Doctors and nurses are ... } & \multicolumn{2}{c}{ Group A } & \multicolumn{2}{c}{ Group B } & \multicolumn{2}{c}{ Total } \\
\cline { 2 - 8 } & $\mathrm{N}$ & $\%$ & $\mathrm{~N}$ & $\%$ & $\mathrm{~N}$ & $\%$ \\
\hline Cool & 9 & 90 & 8 & 80 & 17 & 85 \\
\hline Good & 1 & 10 & 0 & 0 & 1 & 5 \\
\hline Understanding & 0 & 0 & 2 & 20 & 2 & 10 \\
\hline
\end{tabular}

Results presented in Table 3 confirm that children hada positive attitude toward the medical staff. Some $85 \%$ of children considered doctors and nurses as cool individuals while $10 \%$ as understanding individuals.

TABLE 4. Reaction to an opinion: „In hospital , I am irritated by ..."

\begin{tabular}{lcccccc}
\hline \multicolumn{1}{c}{$\begin{array}{l}\text { In hospital, } \\
\text { I am irritated by/when... }\end{array}$} & \multicolumn{2}{c}{ Group A } & \multicolumn{2}{c}{ Group B } & \multicolumn{2}{c}{ Total } \\
\cline { 2 - 7 } & $\mathrm{N}$ & $\%$ & $\mathrm{~N}$ & $\%$ & $\mathrm{~N}$ & $\%$ \\
\hline $\begin{array}{l}\text { The crying of small } \\
\text { children }\end{array}$ & 3 & 30 & 4 & 40 & 7 & 35 \\
\hline I cannot sleep & 1 & 10 & 1 & 10 & 2 & 10 \\
\hline The pain in my legs & 0 & 0 & 1 & 10 & 1 & 5 \\
\hline I am laying on a traction & 1 & 10 & 0 & 0 & 1 & 5 \\
\hline $\begin{array}{l}\text { I have to lay in the ward } \\
\text { corridor }\end{array}$ & 0 & 0 & 1 & 10 & 1 & 5 \\
\hline I have high temperature & 2 & 20 & 0 & 0 & 2 & 10 \\
\hline Too frequent meals & 0 & 0 & 1 & 10 & 1 & 5 \\
\hline Doctor's visits & 3 & 30 & 1 & 10 & 4 & 10 \\
\hline A friend, a room maid & 0 & 0 & 1 & 10 & 1 & 5 \\
\hline
\end{tabular}

There is a huge diversification when it comes to irritating values in Table 4 . The most of the examined children $(30 \%$ from group A and $40 \%$ from group B) pointed to the crying of small children as the most irritating part.

\section{Expectations of ill children}

TABLE 5. Reaction to an opinion ,I hope ..."

\begin{tabular}{lcccccc}
\hline \hline \multirow{2}{*}{ I hope ... } & \multicolumn{2}{c}{ Group A } & \multicolumn{2}{c}{ Group B } & \multicolumn{2}{c}{ Total } \\
\cline { 2 - 7 } & $\mathrm{N}$ & $\%$ & $\mathrm{~N}$ & $\%$ & $\mathrm{~N}$ & $\%$ \\
\hline I will never be ill & 1 & 10 & 2 & 20 & 3 & 15 \\
\hline I will come home soon & 9 & 90 & 7 & 70 & 16 & 80 \\
\hline $\begin{array}{l}\text { I will not be turned down } \\
\text { by my girlfriend/boyfriend }\end{array}$ & 0 & 0 & 1 & 10 & 1 & 5 \\
\hline
\end{tabular}

As it appears from Table 5, the hopes of ill children are very much similar. $80 \%$ of the whole want to get back home, $15 \%$ never want to be ill.

\section{Children's pleasures at the hospital}

TABLE 6. Reaction to an opinion ,The best care is provided by ..."

\begin{tabular}{lcccccc}
\hline \hline \multirow{2}{*}{ The best care is provided by } & \multicolumn{2}{c}{ Group A } & \multicolumn{2}{c}{ Group B } & \multicolumn{2}{c}{ Total } \\
\cline { 2 - 8 } & $\mathrm{N}$ & $\%$ & $\mathrm{~N}$ & $\%$ & $\mathrm{~N}$ & $\%$ \\
\hline Mum & 5 & 50 & 7 & 70 & 12 & 60 \\
\hline Family & 3 & 30 & 2 & 20 & 5 & 25 \\
\hline Grandmother & 0 & 0 & 1 & 10 & 1 & 5 \\
\hline All of them & 2 & 20 & 0 & 0 & 2 & 10 \\
\hline
\end{tabular}

Results in Table 6 show individualswho took best careof children at the hospital. The most -

$60 \%$ of the whole of the examined considered mum as the best person looking afterthem. 


\section{Aversions of ill children}

TABLE 7. Reaction to an opinion „I mostly fear ..."

\begin{tabular}{lcccccc}
\hline \multirow{2}{*}{\multicolumn{1}{c}{ I mostly fear... }} & \multicolumn{2}{c}{ Group A } & \multicolumn{2}{c}{ Group B } & \multicolumn{2}{c}{ Total } \\
\cline { 2 - 7 } & $\mathrm{N}$ & $\%$ & $\mathrm{~N}$ & $\%$ & $\mathrm{~N}$ & $\%$ \\
\hline Operation & 1 & 10 & 2 & 20 & 3 & 15 \\
\hline Coming back to hospital & 1 & 10 & 2 & 20 & 3 & 15 \\
\hline Injections & 5 & 50 & 1 & 10 & 6 & 30 \\
\hline Dogs & 1 & 10 & 1 & 10 & 2 & 10 \\
\hline School & 1 & 10 & 1 & 10 & 2 & 10 \\
\hline Being lonely & 0 & 0 & 1 & 10 & 1 & 5 \\
\hline My father & 1 & 10 & 1 & 10 & 2 & 10 \\
\hline Spiders & 0 & 0 & 1 & 10 & 1 & 15 \\
\hline
\end{tabular}

Table 7 is describing most stressing factors for the ill children. Some of them say about the hospital situation $(30 \%$ of the whole feared injections mostly), other talked about the everyday situation ( $10 \%$ of inspected feared the school).

\section{RESULTS}

Adaptation of children with illnesses of motor organs to conditions of their hospitalizationwas studied with test of unfinished sentences.

Illness and the stay in hospital are a very difficult period in the life of the child. Not always they are able to understand the need for the hospitalization or the need for lying in bed or taking medicines. Children usually have much free time which they do not always know how to fill. They often think about the event which caused their hospitalization. These situations leave a strong, distinct track on the psyche of children. They also evoke intense emotional feelings including the willingness of gladly forgetting about noting that some children are able to positively assess the situation in which they found themselves, they display mature understanding of the need for the hospitalization for the whole process of recovering the organism. The hospital situation is teaching children patience, positive evaluation of the family house, sensitivity to other suffering individuals. For some individuals the hospitalization poses an opportunity for reflection over individual life and family life.

Ill children often think about pleasant, happy experience which they could have had when being healthy (e.g. to play ball). The stay in hospital is creating chance for positive experiences. These are visits of close friends and family, conversations with peers. Positive are also smallest symptoms of recovering of their organism. An increase in a sense of well-being is observed at the lack of the perception of pain.

Apart from the positive assessment of the family house, children also report the need of maintaining contacts with peers. Good mood is accompanying conversations with friends, and hanging out in the good company. Striking is creating new friendship and relationships. There are also children hidden and closed within themselves who have big feeling of loneliness and they are concentrating on their own illness. Some patients are assessing in the negative way the influence of the entire hospital complex situation on their stay.

Judging their stay in hospital, children talking about the positives (e.g. every day at the hospital is interesting) and negatives (e.g. every day at the hospital means suffering). Some individuals express desire for avoiding in the future similar occurrences. Children speak positively about the medical staff.
This testifies to good training forwork, the great commitment and the ability to sacrifice. Analyzing the findings of the study, it is possible to state that children with illnesses of the upper limbs have a more optimistic attitude to their situation. This is related to the possibility of moving, having a larger social circle, the possibility of the joint learning in hospital school or watching TV (a set is located in a living room).

However, children with illnesses of the lower limbs, who in most cases must lie in bed, have a lot of free time, which they don't often know how to fill. Therefore the existing situation is for them less optimistic, and favors negative feelings and feeling of loneliness. The attitude of the staff and visiting individualsexerts huge influence on children's feelings. Their engagement, attentive observation and friendly results, in great measure, in a good and optimistic frame of mind of the little patients.

\section{CONCLUSIONS}

Based on empirical examinations, it is possible to drawthe following conclusions:

A couple of measures should be introduced to make the hospital stay more enjoyable.

1. The hospital visits should be more frequent.

2. Fitting children in rooms according to some clear principles, like age, sex and disease type. Patients who must lie in the corridor should be able to walk.

3. Take care of the greater scope of information given to children, suited with theirage and possibilities of their understanding.

4. Remember that medicine despite using its all resources, knowledge,medical technology, is supposed above all to serve the man, through normal and natural care about him/her.

\section{REFERENCES}

1. Arusztowicz B, Bakowski W. Dziecko kalekie jakiego nie znamy. Warszawa: WSP; 1999.

2. Gasiulowa A. Wrażliwość empatyczna dzieci z dysfunkcją narządu ruchu a ich środowisko rodzinne. Bydgoszcz: WSP; 2003.

3. Bogusz J. Encyklopedia dla pielęgniarek. Warszawa: PZWL; 2008.

4. Aamer N, Abhijit B, Sanjeev S, et al. Fernandes. Complications of Elastic Stable Intramedullary Nailing for treating paediatric long bone fractures. J Orthop. 2013;10(1):17-24

5. Jolly J. Inna strona pediatrii. Poradnik codziennej opieki nad chorymi dziećmi. Warszawa: PZWL; 2007.

6. Hedström EM, Svensson I, Bergström U, Michno P. Epidemiology of fractures in children and adolescents. Acta Orthop. 2010;81(1):148-53.

7. Kowalik S. Wybrane psychospołeczne problemy niepełnosprawności i rehabilitacji. In: H. Sęk. Społeczna psychologia kliniczna. Warszawa: PWN; 2003.

8. Kozakiewicz W, Brzózka B. Biblioteka szpitalna dla pacjentów. Poradnik Warszawa: SBP; 2000.

9. Kulczycki M. Psychologiczne problemy człowieka chorego. Wrocław: OSS; 2012

10. MacMahon RA.Poradnik chirurgii dziecięcej. Warszawa: PZWL;1990.

11. Rembowski J. Metoda projekcyjna w psychologii dzieci i młodzieży. Warszawa: PWN; 2006.

12. Sękowska Z. Pedagogika w lecznictwie. Warszawa: PZWL; 2006.

13. Sękowska Z. Wprowadzenie do pedagogiki specjalnej. Warszawa: WSPS; 2008.

14. Bianba, Berntsen S, Andersen LB, et al. Exercise Capacity and Selected Physiological Factors by Ancestry and Residential Altitude: Cross-Sectional Studies of 9-10-Year-Old Children in Tibet. High Alttude Med Biol. 2014;15(2):162-9

15. Pilch T. Zasady badań pedagogicznych. Warszawa: ŻAK; 2005.

\section{Corresponding author}

Magdalena Brodowicz-Król

Chair and Department of Pediatric Nursing, Health Sciences and Nursing Department,

Medical University of Lublin

6 Profesora Antoniego Gębali Str, 20-093 Lublin

E-mail: magdalena.brodowicz@umlub.pl

tel. 662980412 